\title{
Single particle analysis of the accumulation mode aerosol over the northeast Amazonian tropical rain forest, Surinam, South America
}

\author{
R. Krejci ${ }^{1,2}$, J. Ström ${ }^{1}$, M. de Reus ${ }^{1,3}$, and W. Sahle ${ }^{4, *}$ \\ ${ }^{1}$ Institute of Applied Environmental Research, Air Pollution Laboratory, S 10691 Stockholm, Sweden \\ ${ }^{2}$ Department of Meteorology, Stockholm University, S 10691 Stockholm, Sweden \\ ${ }^{3}$ Max Planck Institute for Chemistry, Department of Air Chemistry, P. O. Box 3060, 55020 Mainz, Germany \\ ${ }^{4}$ National Institute of Working Life, S 17184 Solna, Sweden \\ *now at: Studsvik Nuclear AB, Microstructure and microanalysis, Hot Cell Laboratory, S 61182 Nyköping, Sweden
}

Received: 14 November 2003 - Published in Atmos. Chem. Phys. Discuss.: 26 January 2004

Revised: 14 September 2005 - Accepted: 18 November 2005 - Published: 14 December 2005

\begin{abstract}
Single particle analysis of aerosols particles larger than $0.2 \mu$ m diameter was performed on 24 samples collected over Surinam tropical rain forest and in the adjacent marine boundary layer (MBL) during the LBA-CLAIRE 98 campaign in March 1998. Elemental composition and morphology of 2308 particles was determined using SEM-EDX. The aerosol particles were divided into seven groups according to their chemical composition: organic particles, mineral dust, aged mineral dust, sea salt, aged sea salt, Ca-rich, and biogenic aerosol. However the organic material in aerosol particles cannot be identified directly by SEM-EDX, we present indirect method of detection of organic material using this technique. Samples were further divided with respect to the distinct atmospheric layers present in the tropical troposphere including MBL, continental mixed layer, cloud convective layer, free troposphere and region of deep convection outflow. The organic and mineral dust particles are two major groups observed over the rainforest. In the MBL also sea salt particles represented a large fraction between 15 and $27 \%$. The organic particles control much of the chemical characteristic of the aerosol in the continental tropical troposphere. Their abundance ranged from less than $20 \%$ in the MBL to more than $90 \%$ in the free troposphere between 4.5and 12.6-km altitude. During the transport of the air masses from the MBL over the rain forest, fraction of organic aerosol particles more than doubled, reaching $40-60 \%$ in the continental boundary layer. This increase was attributed to direct emissions of biogenic aerosols from the tropical vegetation. The high fraction of the organic accumulation mode particles in the upper tropical troposphere could be a good indicator for the air masses originated over the tropical rain forest.
\end{abstract}

\footnotetext{
Correspondence to: R. Krejci

(radek@misu.su.se)
}

\section{Introduction}

The Amazon basin represents the largest tropical rain forest ecosystem on Earth covering over 4 millions $\mathrm{km}^{2}$. With increased human activity in Amazonia and related landscape changes (Laurance et al., 2001; Werth and Avissar, 2002), the effort to study biosphere-atmosphere interactions and human influences on those processes have become stronger over the last three decades.

Atmospheric aerosols play an important role in the Earth's climate system, influencing climate directly by absorbing and scattering incoming solar radiation, and indirectly by acting as cloud condensation nuclei (CCN) (Charlson et al., 1992), and thereby affecting the cloud microphysical and optical properties, as well as precipitation rate and lifetime of clouds (Rosenfeld, 2000).

Aerosols consist of many different types of particles. They can be divided into two major groups, primary and secondary aerosols. Primary aerosols, often larger than $1 \mu \mathrm{m}$, are directly emitted into the atmosphere and include sea salt, mineral dust, volcanic emission, fly ash and biogenic particles. Secondary aerosols are formed in the atmosphere via gas-toparticle conversion from gaseous precursors (e.g. $\mathrm{SO}_{2}$, organic gases). The majority of the secondary produced particles are in the sub-micrometer range.

Primary biogenic particles include pollen, spores, bacteria, algae, protozoa, fungi, fragments of leaves, excrements and fragments of insects. Biological activity of microorganisms on leaf surfaces and forest litter also produce aerosol particles. Decaying vegetation can generate small particles, which can act as CCN (Schnell and Vali, 1973). A similar conclusion for bacteria was found by Maki and Willoughby (1978). Fish (1972) suggested that haze observed in forested areas could be due to sub-micrometer particles from electrical generation of biogenic aerosols by leaves.

(C) 2005 Author(s). This work is licensed under a Creative Commons License. 
The formation of secondary organic aerosol is thought to result from oxidation of gaseous organic species by one of three electophilic gases present in the atmosphere: the hydroxyl radical $(\mathrm{OH})$, ozone $\left(\mathrm{O}_{3}\right)$ and nitrate radical $\left(\mathrm{NO}_{3}\right)$ (Jacobson et al., 2000). Some of the products from terpene oxidation have low enough saturation vapor pressure and can, therefore, be a source of the secondary organic aerosols (Janson et al., 2001; Kesselmeier et al., 2002).

In central Amazonia, only two major types of particles where found in conditions undisturbed by biomass burning: soil dust and biogenic aerosol (Artaxo et al., 1990). Estimates of the global production rate of organic aerosols show that forest vegetation is a principle source of atmospheric organic particles (Duce et al., 1983; Houghton et al., 2001). Artaxo et al. (1998) reported results from a large-scale aerosol source apportionment study in Amazonia and one of the major conclusions was that natural biogenic aerosols show a ubiquitous presence over large areas of rain forest. For sites with low influence of biomass burning, the biogenic particles dominate the total aerosol mass and number densities, where organic carbon is a major component (Maenhaut et al., 2002; Talbot et al., 1988). Recent measurements of total aerosol mass and aerosol elemental composition using PIXE in central Brazil during wet season in March-April 1998 shown that approximately $80 \%$ of the aerosol mass is most probably of organic nature (Roberts et al., 2002). Similar results were presented in a study by Artaxo et al. (2002), where the authors compared aerosol composition above the Amazon rain forest during both, wet and dry seasons.

Soil dust is the second most abundant aerosol component observed over the Amazon Basin. Besides the local sources, transport of the Saharan dust over the Atlantic Ocean is important, especially during the winter months, when the InterTropical Convergence Zone (ITCZ) is located south or near the Equator (Prospero et al., 1981). Airborne measurements performed during the LBA-CLAIRE 98 project over Surinam showed episodic elevated concentrations of the Saharan dust up to $700 \mathrm{hPa}$ level over the Surinam and central Amazonia (Formenti et al., 2001).

Aerosol microphysical and chemical properties in troposphere are one of the key parameters controlling cloud microphysical properties in the region (Roberts et al., 2001, 2002) and, consequently, influencing convective activity and hydrological cycle. The convective activity may result in a strong vertical transport of aerosols and trace gases to high altitudes where they can be advected over large distances (Garstang et al., 1988; Scala et al., 1990) and have an impact on the upper tropospheric properties in areas far from the source region.

The majority of previous studies from the Amazon Basin focused on bulk aerosol composition. In only a few cases analysis of individual particles have been performed (Artaxo et al., 1990; Gerab et al., 1998; Wouters et al., 1993). Determination of major aerosol types using bulk analysis gives good overall information about the elements or ions present. The aerosol influence on climate and human health are, however, determined by the individual chemical compounds and the mixing state of the particles. Here the single particle analysis is very useful.

In this study we will present results of single particle analysis of atmospheric aerosol $>0.2 \mu \mathrm{m}$ in diameter collected over Surinam, South America. The measurements were conducted over the tropical rain forest and adjacent part of the Atlantic Ocean at altitudes from $0.2 \mathrm{~km}$ to $12.6 \mathrm{~km}$. We will focus on changes in aerosol composition as a function of latitude and altitude as well as try to link the observations to the major sources and processes controlling the accumulation and coarse modes aerosol distribution over the tropical rain forest during conditions undisturbed by biomass burning.

\section{Experimental}

Aerosol measurements as a part of the Large-Scale Biosphere-Atmosphere Experiment in Amazonia (LBA)Cooperative LBA Airborne Regional Experiment (CLAIRE98) were performed using a Cessna Citation II twinjet aircraft operated by the Technical University of Delft, The Netherlands. Flight operations were based at Zanderij International Airport $\left(5^{\circ} \mathrm{N}, 55^{\circ} \mathrm{W}\right)$, about $50 \mathrm{~km}$ south of Paramaribo, Surinam. The flight duration was typically between 3 and $4 \mathrm{~h}$ and the cruising air speed was around $150 \mathrm{~ms}^{-1}$. In total 10 mission flights were performed between 12 March and 29 March 1998 at different altitudes over Surinam, Guyana and French Guyana. The flights were designed to characterize the aerosols and trace gases over the tropical rain forest with special emphasis on the influence of tropical vegetation on atmospheric composition during conditions undisturbed by intensive biomass burning.

\subsection{Sampling}

Aerosol particles were collected on Nuclepore polycarbonate membrane filters with a pore diameter of $0.4 \mu \mathrm{m}$. Active sampling area was reduced to $7 \mathrm{~mm}$ in diameter using a Teflon filter pad supporting the filter from below. The sampling flow rate was controlled by a critical orifice at 1.7 $\mathrm{Lmin}^{-1}$. Eight filters were preloaded in a custom-made filter holder in advance of each flight. One filter was exposed during take-off and landing as well as during ascends and descends to keep the flow through the inlet constant. The remaining seven filters were exposed during horizontal flight legs only. Sampling times varied from 10 to $30 \mathrm{~min}$ depending on the actual flight plan and samples were collected only in cloud-free air. This strategy allowed us to link the observations to distinct layers in the atmosphere.

Air was brought inside of the aircraft via a forward facing, near-isokinetic inlet, allowing sampling of particles smaller than approximately $4 \mu \mathrm{m}$ in diameter. The upper cut-off diameter is based on impaction losses calculations in 
a T-division in the tubing transporting the aerosol towards different sensors inside the aircraft. Due to the temperature difference between inside and outside of the aircraft, the relative humidity of the sampled air did not exceed $40 \%$, and the particles are, therefore, considered to be sampled in a dried state.

A detailed description of the instrumentation and data processing used to obtain information about the aerosol size distributions and number densities, often referred to in this paper, is presented in de Reus et al. (2001) and Krejci et al. (2003).

Supporting data describing the ambient conditions during the measurement flights (static air temperature, ambient air pressure, wind speed, wind direction, air and ground speed) were recorded by the aircraft data acquisition system. Latitude, longitude and altitude data used in this paper were obtained from the Global Positioning System (GPS) receiver.

\subsection{Single particle analysis}

Prior to the analysis, the $7 \mathrm{~mm}$ sampling spot was cut out from the filter and carbon coated. Single particle analysis was performed using the Scanning Electron Microscope (SEM) JEOL-840 (JEOL, Tokyo, Japan) equipped with Energy Dispersive X-ray Analysis (EDX). A windowless Si(Li) detector (Canberra) with a spectral resolution of $157 \mathrm{eV}$ at $5.9 \mathrm{keV}\left(\mathrm{Mn} \mathrm{K}_{\alpha}\right)$ was initially calibrated with multielemental standards and the calibration was repeatedly checked using Al-Cu standard. This set up allows analysis of light elements $(\mathrm{Z} \geq 5)$, but due to the coating of the sample with carbon and presence of oxygen in the polycarbonate filter, only elements with $\mathrm{Z} \geq 11$ (Na) were considered in the $\mathrm{X}$-ray spectra evaluation. The filament current was adjusted to receive 2000$3000 \mathrm{X}$-ray counts per second at an acceleration voltage of $20 \mathrm{keV}$. The integration time for every X-ray spectrum was set to $100 \mathrm{~s}$. The detection limit of this technique is at best in the order of $1 \%$ of mass, so only major elements present in the particles can be measured. Because of the high current required for the X-ray dispersive analysis and limitations in imaging capabilities of the electron microscope, the size of the analyzed particles was restricted to a diameter $>0.2 \mu \mathrm{m}$. Length and width were measured for each particle and the mean Martin's diameter (Hinds, 1999) was used to size them.

The quantitative accuracy of this technique is at best in the order of a few percent (Fletcher and Small, 1993). There are a number of sources, which introduce uncertainties in the derived elemental fractions. There is an error associated with fitting of each spectra, and uncertainties in the spectra itself arise from such things as the particular abundance of the element, acceleration voltage (changes background of the spectra mostly due to a filter influence), detector properties, dead time of the X-ray detector, count rate and also particle size. The overall error is difficult to examine precisely, but it can be in the range of $10 \%$ depending on element and sample.

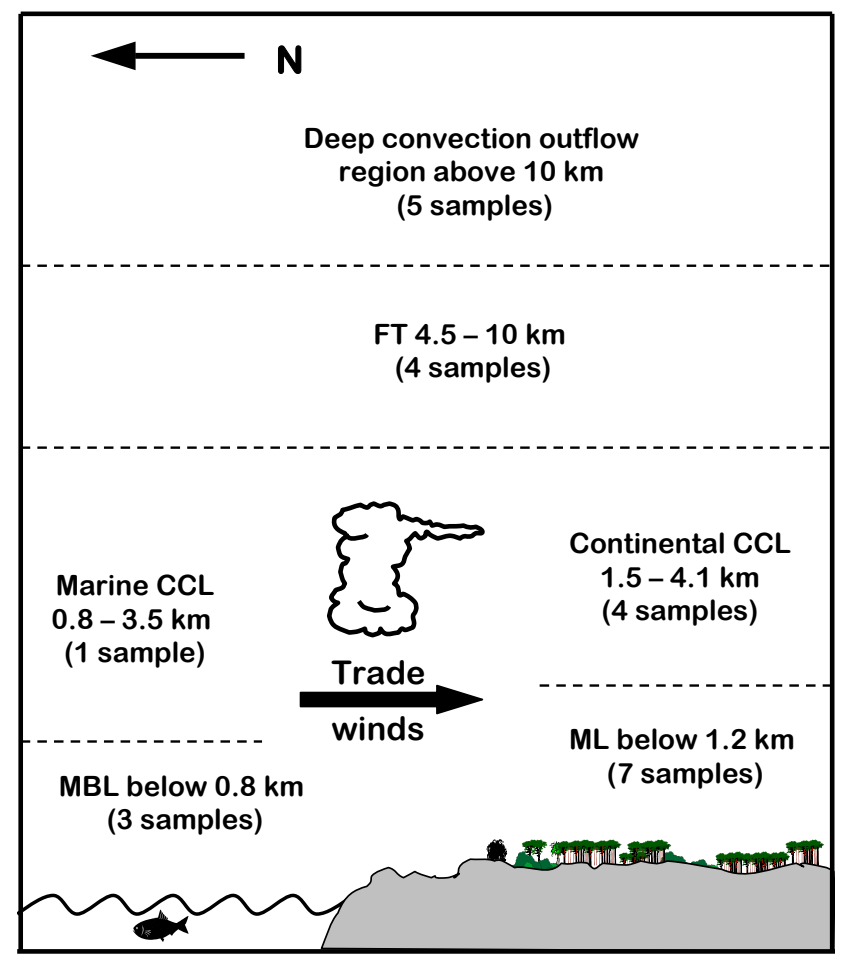

Fig. 1. Schematic picture of the stratification of the samples into the distinct atmospheric layers present in the tropical troposphere over Surinam and the adjacent coastal Atlantic Ocean. The number in parentheses indicates the number of samples analyzed in each layer.

Selection of the particles for elemental analysis was performed manually using a secondary electron image. The analysis started in the middle of the sampling spot and continued in a spiral towards the edge of the filter. Each particle detected, regardless of size and form, was analyzed in succession. About 100 particles were analyzed on every sample. Exceptions are samples from the middle free troposphere (between $4.5 \mathrm{~km}$ and $10 \mathrm{~km}$ ), where only about 70 particles were investigated per filter due to the very low aerosol loading. Number of particles analyzed per sample was relatively low in comparison with other studies (De Bock et al., 2000; Liu et al., 2000) where authors used an automated analytical procedure. As the deposition of the particles on filter is a stochastic process and analytical procedure identical for all filters, we believe that our results are not significantly biased.

\section{Meteorology and atmospheric layers}

Before presenting the aerosol chemical characteristics in different parts of the troposphere (Fig. 1), a short meteorological overview is given to introduce the sample selection procedure. It is also a synopsis for the results presentation and discussion. For a more detailed description of the local 
meteorology with respect to the observed aerosol properties during CLAIRE-98 we refer to Krejci et al. (2003).

Large-scale circulation in the tropics is governed by the seasonally migrating ITCZ, which was located south of Surinam (between $2^{\circ} \mathrm{S}$ and $1^{\circ} \mathrm{N}$ ) during the CLAIRE-98 campaign. The period between February and March, when Surinam is located in the northern meteorological hemisphere, is called the "short dry season". Low-level NNE trade winds transport the air masses at typical wind speeds of 4-6 ms towards the ITCZ, where the air is lifted in large convective systems and then transported northward in the middle and upper troposphere. During the CLAIRE-98, the trade winds extended up to an altitude corresponding to the base of Trade Wind Inversion (TWI) at approximately $2.5-\mathrm{km}$ altitude. Between the base and the top (at approximately $4 \mathrm{~km}$ ) of the TWI the wind direction changed gradually from NNE to ESE. Within the free troposphere winds were highly variable, but the mean southern wind component observed above $6 \mathrm{~km}$ indicates a predominant transport of air from the ITCZ. In this study the term inflow is used for advection towards the ITCZ and outflow is used for advection away from the ITCZ.

The tropical troposphere can be divided into several distinct and semi-persistent layers (Garstang and Fitzjarrald, 1999). The lowermost part of the troposphere, the mixed layer, represents the connection between the surface and the atmosphere. Over the ocean the height of the mixed layer is fairly constant, and close to the Surinam coast it was estimated to be $600-800 \mathrm{~m}$. Over the continent, however, the mixed layer undergoes a distinct diurnal cycle resulting in changes of its height from 200-300 m during night to 1200$1500 \mathrm{~m}$ during daytime (Martin et al., 1988).

Between the mixed layer and the free troposphere the cloud convective layer (CCL) is located. In this layer, shallow convective fair-weather cumuli clouds were present, allowing transport of air from the mixed layer upwards towards the top of the TWI. During CLAIRE-98 the fair-weather cumuli cloud base was observed between 1.4- and 1.8-km altitude. Shallow convective clouds usually do not have enough buoyancy to penetrate through the TWI into the free troposphere. Therefore the TWI can be seen also as a barrier, between the boundary layer and the free troposphere. The top of the TWI was observed between 3.5 and $4.5 \mathrm{~km}$.

Within the tropical cloud-free free troposphere large-scale subsidence prevails, transporting air from the middle and the upper troposphere towards the boundary layer. In the tropics, vertical transport of gases and aerosols in the opposite direction from the boundary layer to the free troposphere is believed to be possible almost exclusively via deep convective clouds (Garstang and Fitzjarrald, 1999).

\section{Results}

More than 50 samples were collected during 10 mission flights between 12 March and 29 March 1998 over the rain forest and over the coastal Atlantic Ocean at altitudes ranging from $0.2 \mathrm{~km}$ to $12.6 \mathrm{~km}$. Single particle analysis is a time and instrumentally demanding analytical method, especially when the SEM available did not allow an automatic analytical procedure. Therefore we selected a representative subset of 24 samples covering the atmospheric conditions encountered during the CLAIRE-98 spatially as well as temporally (Fig. 1). Three samples from the marine boundary layer (MBL) provided information about the nature of the aerosol particles $>0.2 \mu \mathrm{m}$ entering the continent after approximately one week of transport over the Atlantic Ocean. The mixed layer over the rain forest was characterized with seven samples. The remaining 14 samples were used to characterize aerosols in the CCL and in the free troposphere up to 12.6$\mathrm{km}$ altitude.

Based on concurrent aerosol size distribution measurements in the range from 0.006 to $3.5 \mu \mathrm{m}$ (Krejci et al., 2003), we note that the fraction by number of particles larger than $0.2 \mu \mathrm{m}$ is small. In the free troposphere below $10 \mathrm{~km}$ and in the mixed layer over the rain forest this fraction is between 1 and $15 \%$, respectively. If we consider the aerosol volume, using the derived volume aerosol size distributions, particles larger than $0.2 \mu \mathrm{m}$ still represent a minor part $(10 \%)$ of the aerosol volume in the free troposphere below $10 \mathrm{~km}$ and slightly more then $10 \%$ above $10-\mathrm{km}$ altitude. While in the mixed layer aerosols larger than $0.2 \mu \mathrm{m}$ in diameter represent the major fraction (around 90\%) of the aerosol volume.

Using the observed aerosol size distributions from the time periods identical to those when the samples for the single particle analysis were collected we derived the number densities of the particles $>0.2 \mu \mathrm{m}$, denoted from here on as $\mathrm{N}_{200}$. Aerosol number densities are normalized to standard temperature and pressure (1013 $\mathrm{hPa}$ and $273.15 \mathrm{~K})$.

An unavoidable limitation of the SEM-EDX technique is that volatile material will evaporate in high vacuum inside of the SEM chamber. This may cause some particles to shrink or deform, or even disappear completely. Particles potentially affected by this problem have not been treated in any specific way as part of the analysis. Therefore the abundances of certain groups presented later in the paper should be seen as upper limit assuming that certain particles could volatilise in high vacuum present during analysis. The same view should be applied whenever the absolute number density of the specific group of particles is estimated using results of the single particle analysis and independent aerosol size distribution measurements.

\subsection{Particle groups}

The final dataset included 2308 aerosol particles analyzed on 24 filter samples. Based on the results of the elemental composition and morphology, particles were divided into 7 groups (Table 1): Not determined, mineral dust, aged mineral dust, sea salt, aged sea salt, Ca-rich and biogenic particles. 
Table 1. Description of the seven aerosol groups used in the data analysis including the major selection criteria.

\begin{tabular}{|c|c|c|}
\hline Group \# & Elemental associations & Group selection criteria \\
\hline $\begin{array}{c}1 \\
\text { Not determined }\end{array}$ & Not determined & Particles with no X-ray signal detected \\
\hline $\begin{array}{c}2 \\
\text { Mineral dust }\end{array}$ & $\begin{array}{c}\text { Al-Si-Fe } \\
\text { Al-Si-(Na, } \mathrm{Mg}, \mathrm{K}, \mathrm{Ca}, \mathrm{Cl}, \mathrm{Fe}) \\
\text { Fe-rich } \\
\text { Si-rich }\end{array}$ & $\begin{array}{l}\text { Morphology, crystalline structure, } \\
\mathrm{Al}, \mathrm{Si} \text { or Fe are dominant elements. }\end{array}$ \\
\hline $\begin{array}{c}3 \\
\text { Aged mineral dust }\end{array}$ & same as group $\# 2, \mathrm{~S}$ & $\begin{array}{c}\text { Similar characteristics as group } 2 \\
\text { S also detected }\end{array}$ \\
\hline $\begin{array}{c}4 \\
\text { Sea salt }\end{array}$ & $\mathrm{Na}-\mathrm{Cl}, \mathrm{Na}-\mathrm{Cl}-\mathrm{Ca}$ & $\mathrm{Na}+\mathrm{Cl}>50 \%$, morphology \\
\hline $\begin{array}{c}\quad 5 \\
\text { Aged sea salt }\end{array}$ & $\mathrm{Na}-\mathrm{Cl}-\mathrm{S}, \mathrm{Na}-\mathrm{Cl}-\mathrm{S}-\mathrm{Ca}, \mathrm{Na}-\mathrm{S}$ & $\begin{array}{l}\text { Morphology, particles of marine } \\
\text { origin with S }\end{array}$ \\
\hline $\begin{array}{c}6 \\
\text { Ca-rich }\end{array}$ & $\mathrm{Ca}-\operatorname{rich}(\mathrm{Ca}, \mathrm{Ca}-\mathrm{S})$ & $\begin{array}{l}\text { Particles with } \mathrm{Ca} \text { as dominant } \\
\text { element, morphology }\end{array}$ \\
\hline $\begin{array}{c}7 \\
\text { Biogenic particles }\end{array}$ & Ca-K, Na-K-P, Na-Mg-Zn & $\begin{array}{l}\text { Morphology, characteristic minor } \\
\text { elements } \mathrm{Na}, \mathrm{Mg}, \mathrm{K}, \mathrm{P}, \mathrm{Ca}, \mathrm{Zn}\end{array}$ \\
\hline
\end{tabular}

Not determined (ND): (1488 particles) Particles composed of light atomic material $(\mathrm{Z}<11)$ fall into this group. Based purely on their chemical composition, aerosols made of various kinds of organic material, fly ash, soot, and ammonium nitrate belong to this group. Using particle morphology we were able to distinguish among several types of particles within this group. Different kinds of debris, most probably of biogenic origin, were the most common type. A large fraction of the particles, especially in the free troposphere, was not possible to identify. Soot agglomerates and fly ash particles were observed only sparsely. The lateral resolution of the SEM was not good enough to clearly identify spheres in soot agglomerates and therefore their abundance might be actually higher than reported here.

Mineral dust: (535 particles) The term "mineral" is used widely within geological sciences as a description of solids with an uniform composition and ordered structure. In this paper we use the term "mineral" in more narrow meaning, common in atmospheric sciences. The mineral particles include inorganic terrigenous particles, which resided on the Earth surface prior to their lifting to the atmosphere. All mineral dust particles were of irregular shape. The most common types were different kinds of Al-silicates including $\mathrm{Al}-\mathrm{Si}-\mathrm{Fe}$ particles, biotite ( $\mathrm{Si}, \mathrm{Al}, \mathrm{Mg}, \mathrm{K}, \mathrm{Fe}$,), kaolinite ( $\mathrm{Si}, \mathrm{Al})$, pure $\mathrm{Si}\left(\mathrm{SiO}_{2}\right)$ particles and illit-muscovite $(\mathrm{Al}, \mathrm{Si}, \mathrm{K}, \mathrm{Fe})$.

Aged mineral dust: (94 particles) The major characteristics of this group are similar to the group above. In addition, the aged mineral dust particles contained also sulfur. Sulfate can be formed on surface of mineral dust particles during cloud processing or as a result of heterogeneous oxidation of $\mathrm{SO}_{2}$. With respect to previous studies (Andreae et al., 1986), coagulation between aerosol particles or re-entrainment of mineral dust previously deposited on the sea surface are not probable pathways to form this type of aerosol.

Sea salt: (43 particles) Aerosol particles where $\mathrm{Na}$ and $\mathrm{Cl}$ represent either $100 \%$ of the characteristic X-ray counts, or in case of association with Ca more than $50 \%$, belong to this group. The typical cubic crystalline structure was also observed on some of the $\mathrm{Na}-\mathrm{Cl}$ particles collected in the marine boundary layer.

Aged sea salt: (72 particles) Particles composed of elements typical for sea salt aerosol together with sulfur belong to this group. Sulfur dioxide $\left(\mathrm{SO}_{2}\right)$ condense on the sea salt aerosol surface, where it is transformed into sulfate (Sievering et al., 1991). Moreover, sea salt particles are very suitable cloud condensation nuclei and sulfur enrichment can be also result of cloud processing of the sea salt aerosol (Katoshevski et al., 1999). Presence of sulfate indicates that the sea salt aerosol is not freshly produced and resided for some time in the marine boundary layer.

Ca-rich: (33 particles) Particles where calcium was the only detected element or it was associated with sulfur belong to this group. Only 8 particles had a $\mathrm{Ca} / \mathrm{S}$ weight ratio close to that of gypsum (1.25). The $\mathrm{Ca} / \mathrm{S}$ ratio for the other 21 particles was considerably lower. These particles can be a mixture of calcium carbonate and sulfate as a result 
Table 2. Abundance of the different particle groups together with $\pm 1 \sigma$ in individual samples for the sub-micrometer aerosol. The samples are divided into different atmospheric layers presented in the text. $N$ stands for total number of particles $<1 \mu \mathrm{m}$ in a sample.

\begin{tabular}{|c|c|c|c|c|c|c|c|c|c|}
\hline \multirow[t]{2}{*}{$\begin{array}{l}\text { Sampling } \\
\text { date }\end{array}$} & $\begin{array}{l}\text { Altitude } \\
\text { (m) }\end{array}$ & $N$ & $\begin{array}{c}\text { Not } \\
\text { determined }\end{array}$ & $\begin{array}{c}\text { Mineral } \\
\text { dust }\end{array}$ & $\begin{array}{c}\text { Aged } \\
\text { mineral } \\
\text { dust }\end{array}$ & $\begin{array}{l}\text { Sea } \\
\text { salt }\end{array}$ & $\begin{array}{c}\text { Aged } \\
\text { Sea salt }\end{array}$ & Ca-rich & Biogenic \\
\hline & & \multicolumn{8}{|c|}{ \# of particles } \\
\hline & & \multicolumn{8}{|c|}{ Region of deep convective outflow above $10 \mathrm{~km}$} \\
\hline $12 \mathrm{March}$ & 10950 & 71 & $66 \pm 2.2$ & $1 \pm 1$ & & & & $4 \pm 1.9$ & \\
\hline 19 March & 11000 & 88 & $83 \pm 2.2$ & $2 \pm 1.4$ & & $1 \pm 1$ & & $2 \pm 1.4$ & \\
\hline 19 March & 12600 & 90 & 90 & & & & & & \\
\hline 28 March & 11650 & 92 & $84 \pm 2.7$ & & & $6 \pm 2.4$ & & $2 \pm 1.4$ & \\
\hline 29 March & 10650 & 97 & $85 \pm 3.2$ & $3 \pm 1.7$ & & & $1 \pm 1$ & & $8 \pm 2.7$ \\
\hline \multirow{2}{*}{\multicolumn{2}{|c|}{ Sum }} & 438 & $408 \pm 5.3$ & $6 \pm 2.4$ & & $7 \pm 2.6$ & $1 \pm 1$ & $8 \pm 2.8$ & $8 \pm 2.8$ \\
\hline & & \multicolumn{8}{|c|}{ Free troposphere } \\
\hline 12 March & 6750 & 60 & $58 \pm 1.4$ & $1 \pm 1$ & $1 \pm 1$ & & & & \\
\hline 15 March & 8050 & 68 & 68 & & & & & & \\
\hline 17 March & 4770 & 79 & $74 \pm 2.2$ & & & & $1 \pm 1$ & $2 \pm 1.4$ & $2 \pm 1.4$ \\
\hline 29 March & 6140 & 57 & $51 \pm 2.3$ & $1 \pm 1$ & & $5 \pm 2.1$ & & & \\
\hline \multicolumn{2}{|c|}{ Sum } & 264 & $251 \pm 3.5$ & $2 \pm 1.4$ & $1 \pm 1$ & $5 \pm 2.2$ & $1 \pm 1$ & $2 \pm 1.4$ & $2 \pm 1.4$ \\
\hline & & \multicolumn{8}{|c|}{ Continental cloud convective layer } \\
\hline 12 March & 4000 & 74 & $57 \pm 3.6$ & $7 \pm 2.5$ & & & & $10 \pm 2.9$ & \\
\hline 15 March & 4150 & 71 & $53 \pm 3.7$ & $15 \pm 3.4$ & $3 \pm 1.7$ & & & & \\
\hline 29 March & 1550 & 51 & $40 \pm 2.9$ & $11 \pm 2.9$ & & & & & \\
\hline 29 March & 3160 & 57 & $51 \pm 2.3$ & $6 \pm 2.3$ & & & & & \\
\hline \multicolumn{2}{|c|}{ Sum } & 253 & $201 \pm 6.4$ & $39 \pm 5.7$ & $3 \pm 1.7$ & & & $10 \pm 3.1$ & \\
\hline & & \multicolumn{8}{|c|}{ Marine cloud convective layer } \\
\hline 12 March & 3550 & 55 & \multicolumn{6}{|c|}{ Daytime mixed layer over rain forest } & \\
\hline 15 March & 500 & 76 & $35 \pm 4.3$ & $35 \pm 4.3$ & $3 \pm 1.7$ & & & $3 \pm 1.7$ & \\
\hline 15 March & 1000 & 81 & $24 \pm 4.1$ & $53 \pm 4.3$ & & $4 \pm 1.9$ & & & \\
\hline 17 March & 580 & 75 & $34 \pm 4.3$ & $25 \pm 4.1$ & $5 \pm 2.2$ & & $6 \pm 2.3$ & $2 \pm 1.4$ & $3 \pm 1.7$ \\
\hline 17 March & 610 & 74 & $40 \pm 4.3$ & $20 \pm 3.8$ & $7 \pm 2.5$ & $4 \pm 1.9$ & $3 \pm 1.7$ & & \\
\hline 17 March & 620 & 81 & $41 \pm 4.5$ & $29 \pm 4.3$ & $7 \pm 2.5$ & & $4 \pm 1.9$ & & \\
\hline 26 March & 280 & 64 & $29 \pm 4.0$ & $23 \pm 3.8$ & $5 \pm 2.1$ & $7 \pm 2.5$ & & & \\
\hline 29 March & 400 & 35 & $10 \pm 2.7$ & $21 \pm 2.9$ & & & $4 \pm 1.9$ & & \\
\hline \multicolumn{2}{|c|}{ Sum } & 486 & $213 \pm 10.9$ & $206 \pm 10.9$ & $27 \pm 5.1$ & $15 \pm 3.8$ & $17 \pm 4.1$ & $5 \pm 2.2$ & $3 \pm 1.7$ \\
\hline & & \multicolumn{8}{|c|}{ Marine boundary layer } \\
\hline 12 March & 900 & 42 & $12 \pm 2.9$ & $17 \pm 3.2$ & $5 \pm 2.1$ & $3 \pm 1.7$ & $3 \pm 1.7$ & & $2 \pm 1.4$ \\
\hline 21 March & 300 & 67 & $10 \pm 2.9$ & $28 \pm 4$ & $10 \pm 2.8$ & $4 \pm 1.9$ & $15 \pm 3.4$ & & \\
\hline \multirow{2}{*}{\multicolumn{2}{|c|}{ Sum }} & 60 & $5 \pm 2.1$ & $20 \pm 3.7$ & $10 \pm 2.9$ & $7 \pm 2.5$ & $18 \pm 3.5$ & & \\
\hline & & 169 & $27 \pm 4.8$ & $65 \pm 6.3$ & $25 \pm 4.6$ & $14 \pm 3.6$ & $36 \pm 5.3$ & & $2 \pm 1.4$ \\
\hline
\end{tabular}

of $\mathrm{SO}_{2}$ oxidation on the particle surface or cloud processing of aerosol. In the remaining 4 particles only $\mathrm{Ca}$ was observed. Calcium is also important biogenic element and we cannot exclude biogenic origin of some of the Ca-rich particles.

Biogenic particles: (18 particles) Although, a large fraction of the particles from the ND group is most probably of biogenic origin, we introduced a separate group for particles, in which $\mathrm{Na}, \mathrm{Mg}, \mathrm{P}, \mathrm{K}, \mathrm{Ca}$ and $\mathrm{Zn}$ were detected. Several elements are essential tracers present in plants. Earlier studies reported that the transpiration of plants can lead to migration of $\mathrm{Ca}^{2+}, \mathrm{SO}_{4}^{2-}, \mathrm{Cl}^{-}, \mathrm{K}^{+}, \mathrm{Mg}^{2+}$ and $\mathrm{Na}^{+}$to the atmosphere (Nemeruyk, 1970).

More than $98 \%$ of the analyzed particles belong to one of the groups above. The remaining less than $2 \%$ of the particles were composed of $\mathrm{Cu}$ or $\mathrm{Cu}$ mixed with $\mathrm{S}$ (11 particles), Sr-rich (1 particle), V-rich (1 particle), Ti-rich (5 particles), Al-only (3 particles), Cr-rich (3 particles and Cr-Mn (2 particles). Those particles did not fit with their elemental associations, neither with morphology, into any above listed groups. In case of the Ti-rich, Sr-rich and Al-only particles, their origin will be most probably linked to the re-suspended 
Table 3. Abundance of the individual particle groups together with $\pm 1 \sigma$ in every sample for the super-micrometer aerosol. The samples are divided into different atmospheric layers presented in the text. $N$ stands for total number particles $>1 \mu \mathrm{m}$ in a sample.

\begin{tabular}{|c|c|c|c|c|c|c|c|c|c|}
\hline \multirow[t]{2}{*}{$\begin{array}{l}\text { Sampling } \\
\text { date }\end{array}$} & $\begin{array}{l}\text { Altitude } \\
\text { (m) }\end{array}$ & $N$ & $\begin{array}{c}\text { Not } \\
\text { determined }\end{array}$ & $\begin{array}{c}\text { Mineral } \\
\text { dust }\end{array}$ & $\begin{array}{c}\text { Aged } \\
\text { mineral } \\
\text { dust }\end{array}$ & $\begin{array}{l}\text { Sea } \\
\text { salt }\end{array}$ & $\begin{array}{c}\text { Aged } \\
\text { Sea salt }\end{array}$ & Ca-rich & Biogenic \\
\hline & & \multicolumn{8}{|c|}{ \# of particles } \\
\hline & & \multicolumn{8}{|c|}{ Region of deep convective outflow above $10 \mathrm{~km}$} \\
\hline 12 March & 10950 & 25 & $23 \pm 1.4$ & & & & & & $2 \pm 1.5$ \\
\hline 19 March & 11000 & 10 & $9 \pm 0.9$ & $1 \pm 0.9$ & & & & & \\
\hline 19 March & 12600 & & 8 & 8 & & & & & \\
\hline 28 March & 11650 & 13 & $12 \pm 1$ & & & & $1 \pm 1$ & & \\
\hline 29 March & 10650 & 12 & $11 \pm 1$ & $1 \pm 1$ & & & & & \\
\hline \multirow{2}{*}{\multicolumn{2}{|c|}{ Sum }} & 68 & $63 \pm 2.2$ & $2 \pm 1.4$ & & $1 \pm 1$ & & & $2 \pm 1.4$ \\
\hline & & \multicolumn{8}{|c|}{ Free troposphere } \\
\hline 12 March & 6750 & 24 & $23 \pm 1$ & & $1 \pm 1$ & & & & \\
\hline 15 March & 8050 & 8 & 8 & & & & & & \\
\hline 17 March & 4770 & 16 & $15 \pm 1$ & & $1 \pm 1$ & & & & \\
\hline 29 March & 6140 & 19 & 19 & & & & & & \\
\hline \multicolumn{2}{|c|}{ Sum } & 67 & $65 \pm 1.4$ & & $2 \pm 1.4$ & & & & \\
\hline & & \multicolumn{8}{|c|}{ Continental cloud convective layer } \\
\hline 12 March & 4000 & 35 & $26 \pm 2.6$ & $4 \pm 1.9$ & & & & $5 \pm 2.1$ & \\
\hline 15 March & 4150 & 22 & $15 \pm 2.2$ & $6 \pm 2.1$ & $1 \pm 1$ & & & & \\
\hline 29 March & 1550 & 36 & $33 \pm 1.7$ & $3 \pm 1.7$ & & & & & \\
\hline 29 March & 3160 & 31 & 31 & & & & & & \\
\hline \multicolumn{2}{|c|}{ Sum } & 124 & $104 \pm 4$ & $13 \pm 3.4$ & $1 \pm 1$ & & & $5 \pm 2.2$ & \\
\hline & & \multicolumn{8}{|c|}{ Marine cloud convective layer } \\
\hline \multirow[t]{2}{*}{12 March } & 3550 & 34 & $33 \pm 1$ & $1 \pm 1$ & & & & & \\
\hline & & & & Daytime & mixed lay & over $\mathrm{r}$ & in forest & & \\
\hline 15 March & 500 & 12 & $4 \pm 1.6$ & $8 \pm 1.6$ & & & & & \\
\hline 15 March & 1000 & 24 & $5 \pm 2$ & $17 \pm 2.2$ & $2 \pm 1.4$ & & & & \\
\hline 17 March & 580 & 25 & $3 \pm 1.6$ & $16 \pm 2.4$ & $4 \pm 1.8$ & & $2 \pm 1.4$ & & \\
\hline 17 March & 610 & 30 & $4 \pm 1.9$ & $19 \pm 2.6$ & $5 \pm 2$ & & $2 \pm 1.4$ & & \\
\hline 17 March & 620 & 28 & $4 \pm 1.9$ & $20 \pm 2.4$ & & $1 \pm 1$ & & & \\
\hline 26 March & 280 & 29 & $12 \pm 2.7$ & $15 \pm 2.7$ & & & $2 \pm 1.4$ & & \\
\hline 29 March & 400 & 50 & $14 \pm 3.2$ & $33 \pm 3.3$ & $1 \pm 1$ & & $1 \pm 1$ & & $1 \pm 1$ \\
\hline \multicolumn{2}{|c|}{ Sum } & 198 & $46 \pm 5.9$ & $128 \pm 6.7$ & $12 \pm 3.4$ & $1 \pm 1$ & $7 \pm 2.6$ & $3 \pm 1.7$ & $1 \pm 1$ \\
\hline & & \multicolumn{8}{|c|}{ Marine boundary layer } \\
\hline 12 March & 900 & 53 & $14 \pm 3.2$ & $28 \pm 3.6$ & $8 \pm 2.6$ & & $3 \pm 1.7$ & & \\
\hline 21 March & 300 & 31 & $4 \pm 1.9$ & $15 \pm 2.8$ & $8 \pm 2.4$ & & $4 \pm 1.9$ & & \\
\hline 29 March & 150 & 43 & $5 \pm 2.1$ & $28 \pm 3.1$ & $7 \pm 2.4$ & & $3 \pm 1.7$ & & \\
\hline \multicolumn{2}{|c|}{ Sum } & 127 & $23 \pm 4.3$ & $71 \pm 5.6$ & $23 \pm 4.3$ & & $10 \pm 3$ & & \\
\hline
\end{tabular}

mineral dust as all three elements are typically of terrigenous origin. Presence of the $\mathrm{Cu}$-rich particles was first considered as a sign of contamination. It became clear after further detailed investigation of the sampling set-up and laboratory equipment that samples did not get in contact with pure cooper. Moreover, $\mathrm{Cu}$-rich particles were in sub-micrometer size range and of round shape. In case of contamination during sampling or filter handling one would expect larger, super-micrometer, particles with irregular shape. Therefore, we believe that $\mathrm{Cu}$-rich particles were present in the atmosphere, but their origin is unclear. We did not observe any pattern in the distribution of the Cu-rich particles, neither spatial, nor a relation to any other group, and so $\mathrm{Cu}$-rich particles, contributing to the overall number by only $0.5 \%$, were excluded from the analysis.

The distribution of different groups of particles will be discussed with respect to the major layers in the tropical troposphere introduced earlier in the paper. Furthermore, the particles were divided into two groups with respect to the particle size: particles $<1 \mu \mathrm{m}$ (sub-micrometer aerosol) and particles $>1 \mu \mathrm{m}$ (super-micrometer aerosol). A summary of the particle abundances belonging to each group in the individual 

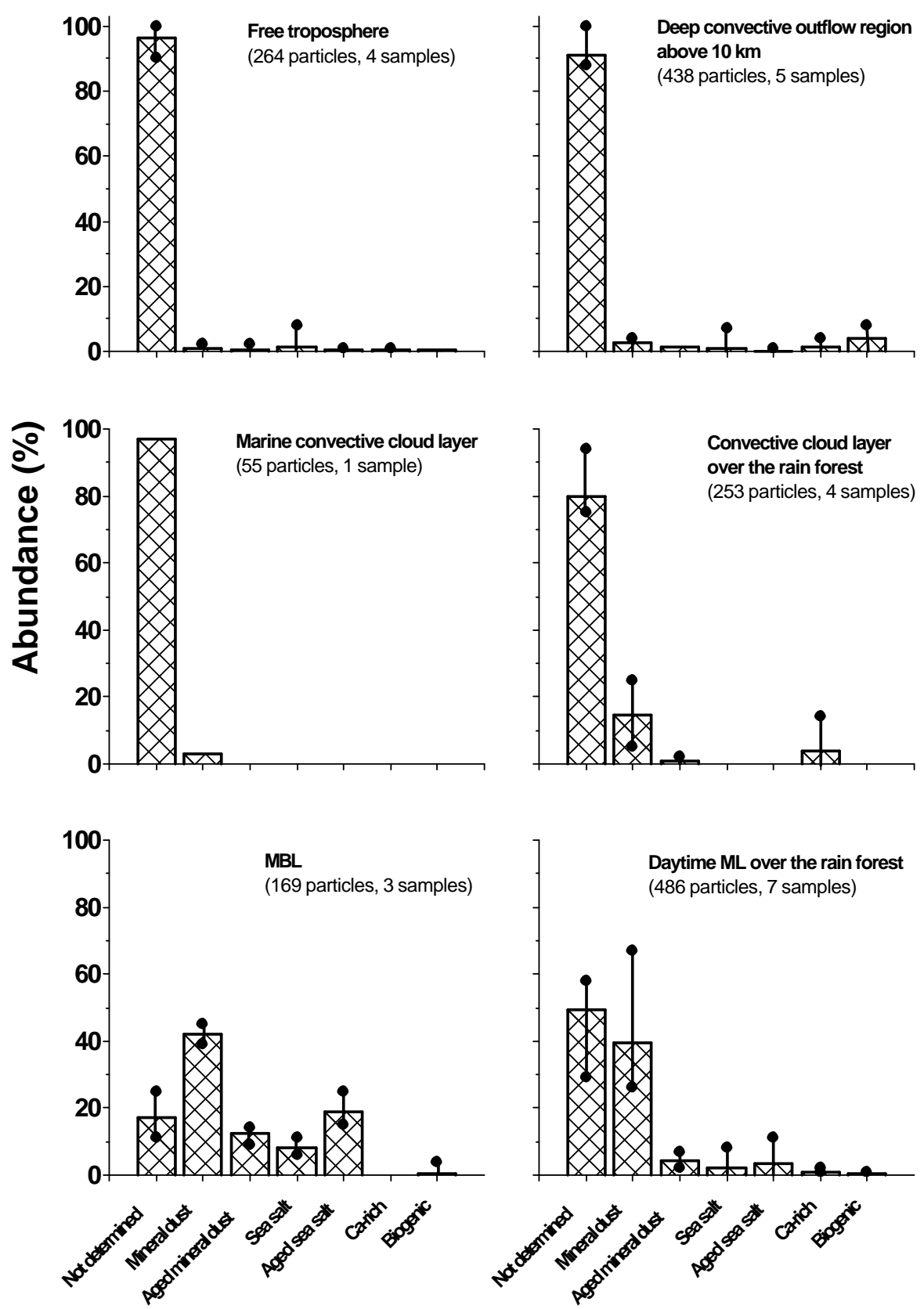

Fig. 2. Abundance of the defined aerosol groups in the sub-micrometer aerosol within six distinct layers. Vertical lines indicate range of the abundances based on individual samples. In case the lowest observed abundance was zero, the lower limit dot is not displayed.

samples can be found in Tables 2 and 3. Standard deviations $\sigma$ listed in these tables are calculated using equations from Ebert et al. (2000).

$\sigma=\sqrt{N * p_{i} *\left(1-p_{i}\right)}$

where

$p_{i}=\mu_{i} / N$ with $N$ representing the total number of particles analyzed and $p_{i}$ the probability of a particle to fall in group $i$. The $\mu_{i}$ stands for the absolute number of particles in group $i$.

\subsection{Marine boundary layer}

Three samples were collected in the marine boundary layer between 200- and 800-m altitude over the Atlantic Ocean during the flights on 12, 21 and 29 March. Mineral dust 


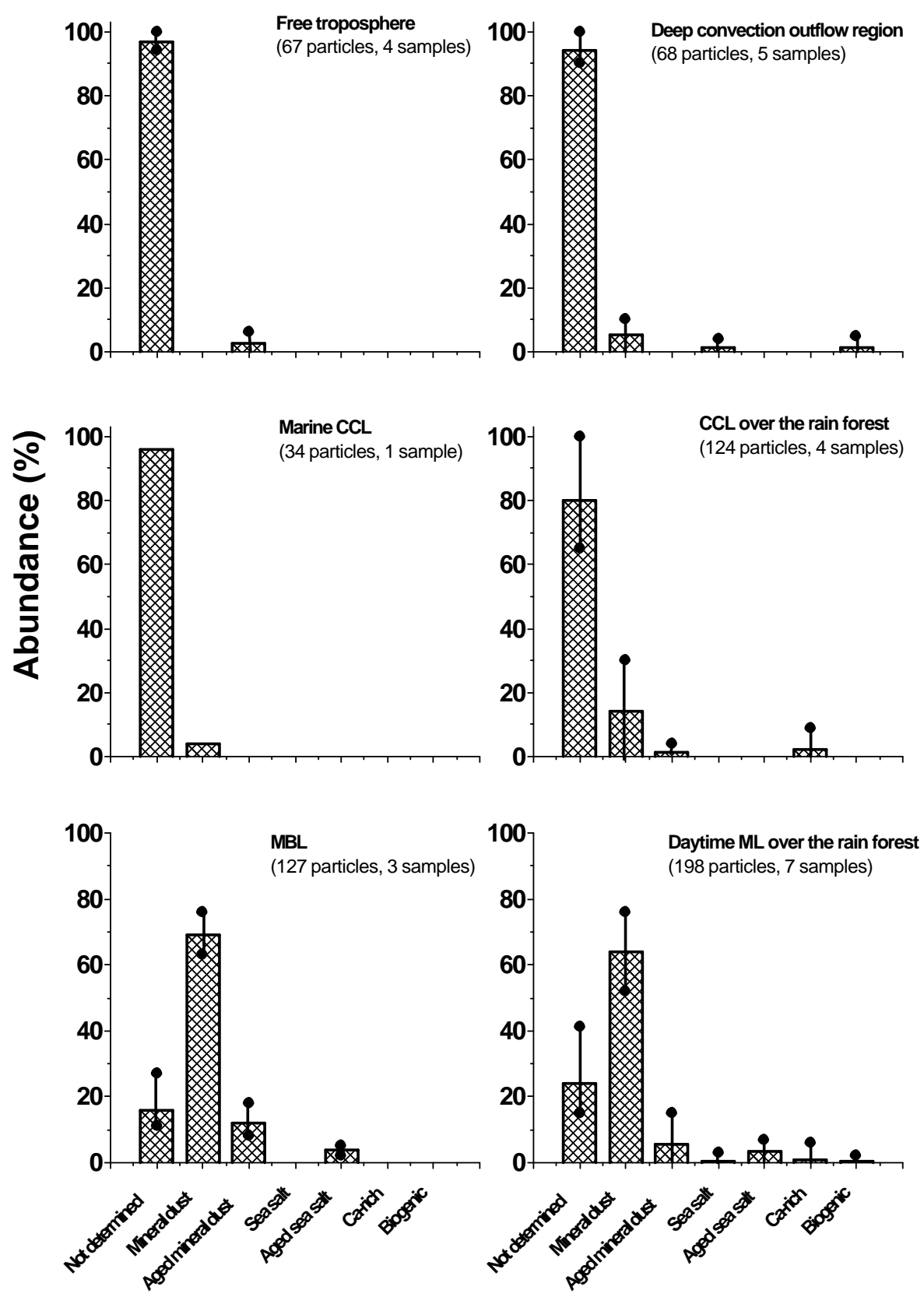

Fig. 3. Abundance of the defined aerosol groups in the super-micrometer aerosol within six distinct layers. Vertical lines indicate range of the abundances based on individual samples. In case the lowest observed abundance was zero, the lower limit dot is not displayed.

particles were the most abundant particle group in both size fractions (Figs. 2 and 3) representing $42 \%$ of the submicrometer and $69 \%$ of the super-micrometer particles. The second most abundant particle type, $17 \%$ in the sub-micron group and $16 \%$ in the super-micron group, was the ND group.

The sea salt particles and aged sea salt particles fractions were higher in the sub-micrometer size range compared to the super-micrometer size range. Moreover, the aged sea salt particles were approximately 2 times more abundant than the pure sea salt particles. The pool of the aged sea salt group is comparable to the ND group. In the supermicrometer aerosol only few aged sea salt particles were observed. In clean marine background conditions observed during the MAST experiment, sea salt particles represented $77 \%$ of the aerosol $>0.2 \mu \mathrm{m}$ (De Bock et al., 2000). Lower relative abundance of sea salt particles in the MBL found during the CLAIRE-98 campaign may be due to a contribution of long-range transported mineral dust aerosols from the Sahara desert (Formenti et al., 2001). Another factor may 


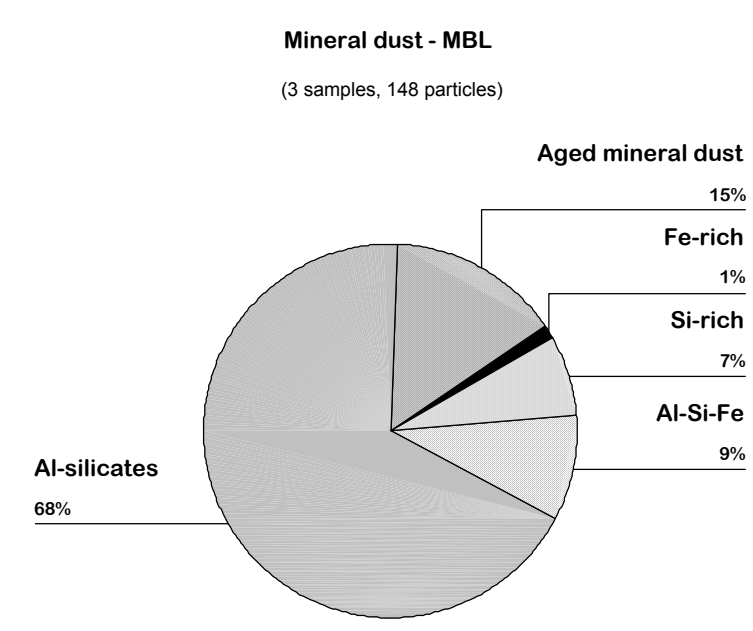

Mineral dust - ML over rain forest

(7 samples, 339 particles)

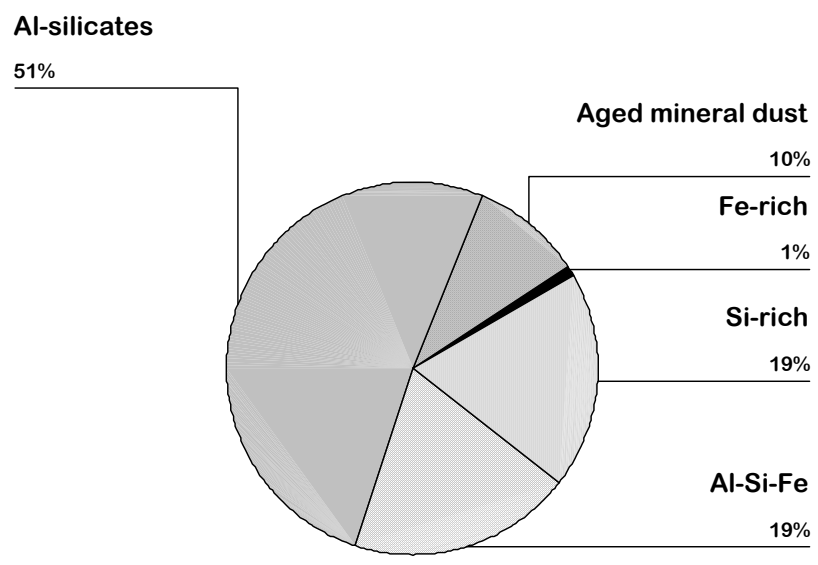

Fig. 4. Stratification of the mineral dust particles observed in the MBL and in the mixed layer over the rain forest based on the different elemental associations.

be the history of surface winds experienced by the air mass. The emissions of sea salt particles increase with increasing wind speed (O'Dowd and Smith, 1993) and in a situation where the wind speed has been low for an extended period of time, the pool of hygroscopic material may be washed-out in relation to the non-hygroscopic particles. Hence, the sea salt particles present in this situation would probably be old cloud droplet residues, which is consistent with our findings of a relatively large abundance of "aged sea salt" particles and low trade wind speeds.

\subsection{Continental mixed layer}

As the marine air is transported with the trade winds over the continent, sources located inland modify the aerosol composition. Seven samples were collected on 15 (2 samples),
17 (3 samples), 26, and 29 March over the tropical rain forest south of $4.5^{\circ} \mathrm{N}$.

There are no indications of a significant influence by the anthropogenic sources located in the coastal region of Surinam as we did not observed an enhancement of soot or fly ash particles. This is also supported by the carbon monoxide measurements, which did not show elevated mixing ratios associated with anthropogenic activities in the coastal region (Williams et al., 2001).

Five of the samples presented very similar signatures, whereas two samples collected on 15 and 29 March were different and more similar to the MBL samples. These two samples showed a lower abundance of ND particles and a higher abundance of mineral particles in comparison to the other continental mixed layer samples. Notes taken during the flight reveal that both samples were collected in a region with local convective precipitation. In the samples collected in the air not affected by precipitation, the ND-type of particle in the sub-micrometer size range increased from below $20 \%$ in the MBL to about 50\% over the rainforest at the expense of the aged mineral particles, sea salt and aged sea salt particles. The super-micrometer size range presented the same trend, but the change was smaller. Together, the ND group, mineral dust and aged mineral dust groups make up almost $90 \%$ of the analyzed particles in both the sub- and super-micrometer size ranges over the rainforest. The larger abundance of mineral dust particles in the samples affected by precipitation may be due to the ND type of particles being more hygroscopic than the mineral particles and therefore washed out from the atmosphere, which is analogue to the situation for sea salt particles in the MBL. Another possibility is that the source of ND particles may be inhibited by precipitation. In want of more information we can only speculate about the reason for the difference between the precipitating and non-precipitating cases.

Scaling the size distribution measurements with the concurrent abundances allow us to estimate the absolute number of different particle types. The mineral dust number density in the MBL ranges from 13 to $22 \mathrm{~cm}^{-3}$. However, over the continent the observed mineral dust aerosol number densities were higher, between 24 and $38 \mathrm{~cm}^{-3}$. At the same time as the number density of mineral particles increased, there was also a shift in the composition as the air mass moved in over the continent. The Al-Si-Fe particles as well as Si-rich particles are relatively more abundant over the land in comparison with the MBL, indicating possible influence from local sources (Fig. 4). Surinam and both surrounding Guyanas are one of the world leading suppliers of aluminum ore (bauxite) and mining activities in the coastal region is apparently a local source of mineral aerosol.

The $\mathrm{N}_{200}$ particle number density in the MBL was 20 $40 \mathrm{~cm}^{-3}$. With respect to the fraction of sea salt particles in the MBL this corresponds to $4-10 \mathrm{~cm}^{-3}$. In the mixed layer over the rain forest the corresponding number density 


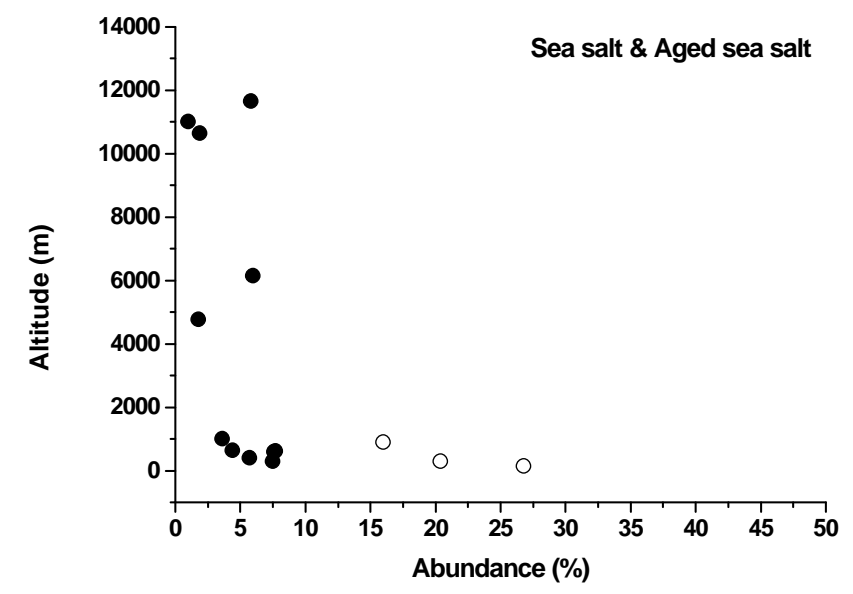

Fig. 5. Vertical distribution of the "sea salt" and "aged sea salt" particles. Both groups are combined together. The samples from the MBL are marked with open circles. The rest of the samples are black dots.

was $0-4 \mathrm{~cm}^{-3}$. Evidently a reduction in the ocean derived aerosol (Fig. 5) as the air moves in over the continent.

\subsection{Cloud convective layer}

The air masses investigated in the cloud convective layer (CCL) are a mixture of air transported from the mixed layer and air entrained from the free troposphere. During convective lifting from the mixed layer, aerosol particles have to be transported via shallow convective fair-weather cumuli clouds and in-cloud processes modify the aerosol composition. The accumulation mode aerosol entrained from the free troposphere was most probably also altered by the same processes. One should remember that we discuss the composition of aerosol particles larger than $0.2 \mu \mathrm{m}$. These particles are too big to be formed in-situ in the free troposphere and their presence here is most probably a result of transport from the boundary layer by deep convection (Krejci et al., 2003; Williams et al., 2002).

There is a considerable difference between the composition of the aerosol in the mixed layer and the composition of the aerosol observed in the CCL. In both size ranges the particles are almost entirely made up of ND type of particles, with an abundance of more than $95 \%$ in the marine CCL (one filter sample) and approximately $80 \%$ (ranging from 65 to $100 \%$ ) in the continental CCL. The compliment is mainly made up of mineral type particles. On 12 March, over the pristine rain forest at $2^{\circ} \mathrm{N}$ around $10 \%$ of the particles were Ca-rich particles in the super micrometer range.

\subsection{Free troposphere and deep convection outflow}

Within the free troposphere, between 4.5 and $10 \mathrm{~km}$, the composition of the aerosol particles $>0.2 \mu \mathrm{m}$ showed a very uniform pattern. Due to the absence of the direct influence

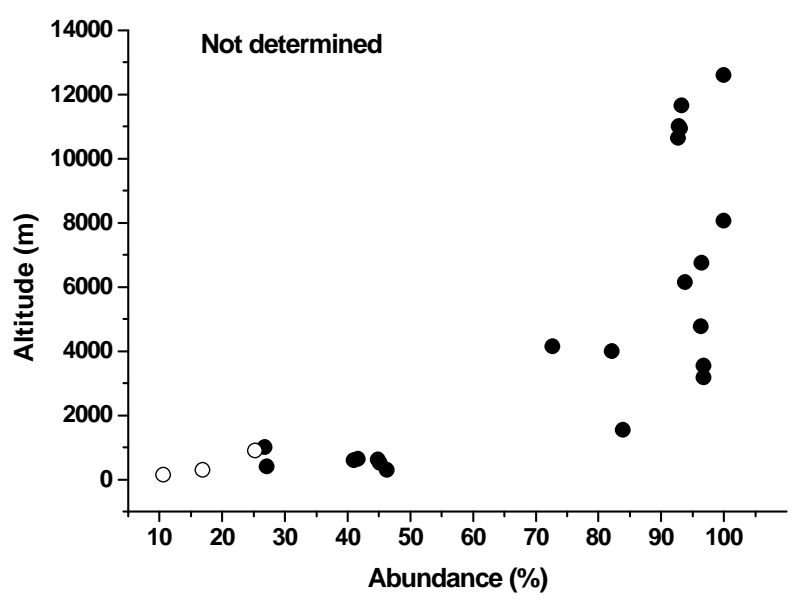

Fig. 6. Vertical distribution of the "not determined" ND group of particles. Samples from the MBL are marked with open circles. The rest of the samples are black dots.

of air from the boundary layer below, we did not distinguish between marine and continental samples. As for the CCL, the aerosols are made up almost entirely of ND particles (Fig. 6). In the sub-micrometer size range we detected also 6 sea salt particles (corresponding to $8 \%$ fraction in the sub-micrometer size range) in the sample from 29 March obtained at $6.1-\mathrm{km}$ altitude. The observed aerosol size distribution from this flight level is different from the other aerosol size distributions observed in the free troposphere between 4.5 and $10 \mathrm{~km}$. It has a pronounced accumulation mode and analysis of the air mass origin using back trajectories points to convective lifting of the air mass over the Atlantic Ocean 2-3 days prior the measurements (Krejci et al., 2003).

Above 10-km altitude, the aerosol composition was similar to the free troposphere below, however, several mineral dust, sea salt, Ca-rich and biogenic particles were also detected. Outflow from deep convective clouds was observed at this altitude during the CLAIRE-98 campaign. This region is characterized by enhanced aerosol number densities (Krejci et al., 2003) as well as by higher mixing ratios of trace gases originating in the boundary layer, for example acetone (Poschl et al., 2001). The "not determined" group still dominates the aerosol composition representing $88-100 \%$ of the analyzed particles. A few particles belonging to the "biogenic group" were observed in samples from 12 March and 29 March. The presence of sea salt aerosol in the sample from 28 March at $11.6 \mathrm{~km}$ altitude can be explained similar to the observations from 29 March at 6.1-km altitude. The air mass history analysis and shape of the size distribution also suggest convective lifting over the tropical Atlantic Ocean several days prior to our measurements. 


\section{Discussion and conclusions}

Using derived aerosol number densities from the size distribution measurements it is possible to estimate the upper limit contribution of different types of particles to the integral aerosol number densities. The particles larger than $1 \mu \mathrm{m}$ represented less than $1 \%$ of the aerosol $>0.2 \mu \mathrm{m}$ and therefore we only used the integral aerosol number densities between 0.2 and $1 \mu \mathrm{m}\left(\mathrm{N}_{200-1000}\right)$ and the abundances of the particle groups in the sub-micrometer range (Table 2).

The $\mathrm{N}_{200-1000}$ number densities in the MBL varied between $21-43 \mathrm{~cm}^{-3}$, and they were approximately two times lower compared to the number densities observed in the mixed layer over land $\left(62-85 \mathrm{~cm}^{-3}\right)$. The corresponding number densities of ND type particles were $2-10 \mathrm{~cm}^{-3}$ in the MBL and $30-45 \mathrm{~cm}^{-3}$ over land in conditions undisturbed by precipitation. All samples from the continental mixed layer were collected during the afternoon, about $300-450 \mathrm{~km}$ from the coast. The air masses had been in contact with the rainforest during at least last 7 to $12 \mathrm{~h}$. Because we can rule out the significant influence of anthropogenic sources and biomass burning on our samples (Williams et al., 2001), and the fact that the number density of accumulation mode particles was 20 times lower in the CCL, we can be sure that source of the majority of the ND type particles is the rain forest.

Our observations can be compared to previous studies from the Amazon Basin. Size resolved measurements from central Amazonia near Manaus, about $700 \mathrm{~km}$ south west of our operation area, showed the dominance of the biogenic aerosols in the size ranges below $1 \mu \mathrm{m}$ and above $2 \mu \mathrm{m}$ in diameter. Aerosols between one and two micrometers were mostly of mineral dust nature (Artaxo and Hansson, 1995). Single particle analysis from the same site also showed a presence of only two major types of particles: mineral dust and biogenic aerosols (Artaxo et al., 1990). Echalar et al. (1998) found, during the long-term aerosol chemistry measurements at two sites in Amazonia, that during the wet season biogenic aerosols dominated the aerosol population. Talbot et al. (1988) concluded, based on the results from the ABLE projects, that the moist forest ecosystem is a source of aerosols, composed of material directly released by vegetation.

Using the SEM-EDX technique in combination with polycarbonate filters we cannot directly detect and quantify organic matter in the aerosol particles, however, with respect to previous measurements and indirect evidence presented in this paper, we are confident that the ND group of particles contains dominantly organic aerosol particles, most probably of biogenic origin. Detail discussion of the method used to identify organic aerosol particles with the SEMEDX technique is discussed in interactive discussion of this paper at: http://www.cosis.net/members/journals/df/article. php?a_id=499.
The mechanisms of biogenic aerosol emissions are still not fully understood, but probably include mechanical abrasion by wind, biological activity of microorganisms on plant surfaces and forest litter and plant physiological processes such as transpiration and guttation.

Our measurements showed the increasing importance of organic matter in the composition of the particles $>0.2 \mu \mathrm{m}$ in the free troposphere between 4 and $12.6 \mathrm{~km}$. More than $90 \%$ of the particles observed at this altitude are of organic nature.

It is generally assumed that only particles composed of highly soluble inorganic material will be activated into cloud droplets. Only recently it was considered that also particles composed of soluble organic material can be activated as cloud droplets (Kulmala et al., 1996). Novakov and Penner (1993) reported a significant contribution of organic material in the total CCN mass in the MBL over the Caribbean Sea, especially in sub-micrometer range. The high CCN/CN ratio observed near Manaus in the central Amazonia resembles more marine conditions than typical continental conditions and particles larger than $0.06 \mu \mathrm{m}$ will be most probably activated as CCN (Roberts et al., 2001). Given the observations presented in this study, that the rainforest is the source of accumulation mode particles, and the strong reduction of these particles in the CCL, put an interesting link between the natural source of $\mathrm{CCN}$ and cloud properties. Because the rainforest is a self-contained ecosystem, which produces its own necessary $\mathrm{CCN}$, any natural or anthropogenicallyinduced changes affecting the processes producing these particles may in turn affect the clouds and precipitation in the region.

There are no known sources of comparable intensity from the ocean surface that would produce particles that would fall into the organic ND group and other compounds as sea salt and sulfate will dominate the remote marine accumulation mode aerosol (Quinn et al., 2000). Due to the more soluble mass present, these particles are better CCN than organic aerosol and in-cloud processes and precipitation remove them efficiently from the atmosphere. Ikegami et al. (1994) reported a high fraction (42-60\%) of sea salt particles in the upper tropical troposphere above $11 \mathrm{~km}$ altitude over the western tropical Pacific Ocean in the vicinity of deep convective clouds. However, the accumulation mode aerosol $(>0.15 \mu \mathrm{m})$ number densities were below $10 \mathrm{~cm}^{-3}$, more then five times lower then the accumulation mode $(>0.12 \mu \mathrm{m})$ number densities observed at this altitude during the CLAIRE campaign (Krejci et al., 2003). If the number densities of accumulation mode particles presented above are representative for the two regions, the importance of the biogenic organic particles for the upper tropospheric aerosol budget may be much larger than suggested simply from the fraction of rainforests in the tropics due to a semi-continuous export of these particles. Moreover, the regions with the most intensive deep convection are located over the tropical rain forests of Amazonia, central Africa and south-east Asia 
(Chelliah and Arkin, 1992).

The knowledge about the aerosol composition and the mixing state of particles in the upper tropical troposphere is still very limited. The results available suggest, that the high fraction of the organic accumulation mode particles in the upper tropical troposphere can be a good indicator for air masses originating over the tropical rain forest. The type of particles exported from the Amazon Basin is a type of aerosol that has survived transport through the CCL or deep convection. The ground-based H-TDMA measurements (Zhou et al., 2001) indicate a significant amount of particles with low hygroscopic growth factors. It is possible that the ND particles observed in the free troposphere belong to these less hygroscopic particles and that clouds did not scavenge them so efficiently as more hygroscopic particles. However, they could also be residual particles from evaporated hydrometeors, but this would mean that in-cloud processes did not add any detectable amounts of $\mathrm{S}$ or other elements with a $\mathrm{Z}>11$.

To learn more about processes forming these particles and the role they may play far away from the source region, requires a more detailed knowledge of their chemical composition and response to changes in ambient humidity.

Acknowledgements. We would like to thank the crew and technicians of the Cessna Citation aircraft and the Suriname Meteorological Office for their support during the whole campaign, together with KNMI for the flow field calculations. This research is part of the project Large-Scale Biosphere/Atmosphere Experiment in Amazonia (LBA). The campaign has been performed within the international research school COACh (Collaboration on Oceanic, Atmospheric and Climate Change Studies) supported by the German and Dutch Ministries of BMBF and OC\&W, respectively, and by the Max-Planck-Society. Special acknowledgement goes to L. Bäcklin and N. Walberg from Stockholm University for their technical assistance in payload construction. The Swedish Research Council (Vetenskaprådet), former Swedish Natural Science Council (NFR), financially supported Swedish group participation on the LBA-CLAIRE 98 project.

Edited by: A. Petzold

\section{References}

Andreae, M. O., Charlson, R. J., Bruynseels, F., Storms, H., Van Grieken, R., and Maenhaut, W.: Internal mixture of sea salt, silicates, and excess sulfate in marine aerosols, Science, 232, 16201623, 1986.

Artaxo, P., Fernandes, E. T., Martins, J. V., Yamasoe, M. A., Hobbs, P. V., Maenhaut, W., Longo, K. M., and Castanho, A.: Largescale aerosol source apportionment in Amazonia, J. Geophys. Res., 103, 31 837-31 847, 1998.

Artaxo, P. and Hansson, H. C.: Size distribution of biogenic aerosol particles from the Amazon basin, Atmos. Environ., 29, 393-402, 1995.

Artaxo, P., Maenhaut, W., Storms, H., and Van Grieken, R.: Aerosol characteristics and sources for the Amazon Basin during the wet season, J. Geophys. Res., 95, 16971-16 985, 1990.
Artaxo, P., Martins, J. V., Yamasoe, M. A., Procópio, A. S., Pauliquevis, T. M., Andreae, M. O., Guyaon, P., Gatti, L. ., and Leal, A. M. C.: Physical and chemical properties of aerosols in the wet and dry seasons in Rondonia, Amazonia, J. Geophys. Res., 107, article\# 8081, doi:10.1029/2001JD000666, 2002.

Charlson, R. J., Schwartz, J. M., Hales, J. M., Cess, J. A., Coakley, J. A. J., Hansen, J. E., and Hofmann, D. J.: Climate forcing by anthropogenic aerosols, Science, 255, 423-430, 1992.

Chelliah, M. and Arkin, P.A.: Large-scale interannual variability of outgoing longwave radiation anomalies over the global tropics, J. Clim., 5, 371-389, 1992.

De Bock, L. A., Joos, P. E., Noone, K. J., Pockalny, R. A., and Van Grieken, R. E.: Single particle analysis of aerosols, observed in the marine boundary layer during the Monterey Area Ship Tracks Experiment (MAST), with respect to cloud droplet formation, J. Atmos. Chem., 37, 299-329, 2000.

de Reus, M., Krejci, R., Williams, J., Fischer, H., Scheele, R., and Ström, J.: Vertical and horizontal distributions of the aerosol number concentration and size distribution over the northern Indian Ocean. J. Geophys. Res., 106, 28 629-28 641, 2001.

Duce, R. A., Mohnen, V. A., Zimmerman, P. R., Grosjean, D., Cautreels, W., Chatfield, R., Jaenicke, R., Ogren, J. A., Pellizzari, E. D., and Wallace, G. T.: Organic material in the global troposphere. Rev. Geophys., 21, 921-952, 1983.

Ebert, M., Weinbruch, S., Hoffmann, P., and Ortner, H. M.: Chemical characterization of North Sea aerosol particles, J. Aerosol. Sci., 31, 613-632, 2000.

Echalar, F., Artaxo, P., Martins, J. V., Yamasoe, M., Gerab, F., Maenhaut, W., and Holben, B.: Longterm monitoring of atmospheric aerosols in the Amazon Basin: Source identification and apportionment. J. Geophys. Res., 103, 31 849-31 864, 1998.

Fish, B. R.: Electrical generation of natural aerosols from vegetation. Science, 175, 1239-1240, 1972.

Fletcher, R. A. and Small, J. A.: Analysis of individual collected particles, in: Aerosol measurement: Principles, techniques and applications, edited by: Baron, P. A., Van Nostrand Reinhold, New York, 260-295, 1993.

Formenti, P., Andreae, M. O., Lange, L., Roberts, G., Cafmeyer, J., Rajta, I., Maenhaut, W., Holben, B. N., Artaxo, P., and Lelieveld, J.: Saharan dust in Brazil and Suriname during the Large-Scale Biosphere-Atmosphere Experiment in Amazonia (LBA) - Cooperative LBA Regional Experiment (CLAIRE) in March 1998, J. Geophys. Res., 106, 14 919-14 934, 2001.

Garstang, M. and Fitzjarrald, D. R.: Observations of surface to atmosphere interactions in the tropics. Oxford University Press, New York, 405, 1999.

Garstang, M., Scala, J., Greco, S., Harriss, R., Beck, S., Browell, E., Sachse, G., Gregory, G., Hill, G., Simpson, J., Tao, W. K., and Torres, A.: Trace gas exchanges and convective transports over the Amazonian rain forest, J. Geophys. Res., 93, 1528-1550, 1988.

Gerab, F., Artaxo, P., Swietlicki, E., and Pallon, J.: Scanning proton microprobe applied to analysis of individual aerosol particles from Amazon Basin, Nuc. Instr. \& Methods B, 136-138, 318323, 1998.

Hinds, W. C.: Aerosol technology - Properties, behavior and measurement of airborne particles, John Wiley \& Sons, New York, 483, 1999.

Houghton, J. T., Ding, Y., Griggs, D. J., Noguer, M., van der Lin- 
den, P. J., Dai, X., Maskell, K., and Johnson, C. A. (Eds.): IPCC 2001: Climate Change 2001: The Scientific Basis. Contribution of Working Group I to the Third Assesment report of the Intergovernmental Panel on Climate Change. Cambridge University Press, Cambridge, UK \& USA, 881, 2001.

Ikegami, M., Okada, K., Zaizen, Y., and Makino, Y.: Sea-salt particles in the upper tropical troposphere, Tellus Ser. B-Chem. Phys. Meteorol., 46, 142-151, 1994.

Jacobson, M. C., Hansson, H. C., Noone, K. J., and Charlson, R. J.: Organic atmospheric aerosols: Review and state of the science, Rev. Geophys., 38, 267-294, 2000.

Janson, R., Rosman, K., Karlsson, A., and Hansson, H.-C.: Biogenic emissions and gaseous precursors to forest aerosols, Tellus, 53B, 423-440, 2001.

Katoshevski, D., Nenes, A., and Seinfeld, J. H.: A study of processes that govern the maintenance of aerosols in the marine boundary layer, J. Aerosol Sci., 30, 503-532, 1999.

Kesselmeier, J., Kuhn, U., Rottenberger, S., Biesenthal, T., Wolf, A., Schebeske, G., Andreae, M. O., Ciccioli, P., Brancaleoni, E., Frattoni, M., Oliva, S. T., Botelho, M. L., Silva, C. M. A., and Tavares, T. M.: Concentrations and species composition of atmospheric volatile organic compounds (VOCs) as observed during the wet and dry season in Rondonia (Amazonia), J. Geophys. Res., 107, artcile \# 8053, doi:10.1029/2000JD000267, 2002.

Krejci, R., Ström, J., de Reus, M., Hoor, P., Williams, J., Fischer, H., and Hansson, H.-C.: The evolution of aerosol properties over the rainforest in Surinam, South America observed from aircraft during the LBA-CLAIRE experiment. J. Geophys. Res., 108, paper \#: 4561, doi:10.1029/2001JD001375, 2003.

Kulmala, M., Korhonen, P., Vesala, T., Hansson, H. C., Noone, K., and Svenningsson, B.: The effect of hygroscopicity on cloud droplet formation, Tellus, 48B, 347-360, 1996.

Laurance, W. F., Cochrane, M. A., Bergen, S., Fearnside, P. M., Delamonica, P., Barber, C., D'Angelo, S., and Fernandes, T.: Environment: The Future of the Brazilian Amazon, Science, 291, 438-439, 2001.

Liu, X., van Espen, P., Adams, F., Cafmeyer, J., and Maenhaut, W.: Biomass burning in Southern Africa: Individual particle characterization of atmospheric aerosols and savana fire samples, J. Atmos. Chem., 36, 135-155, 2000.

Maenhaut, W., Fernandez-Jimenez, M. T., Rajta, I., and Artaxo, P.: Two-year study of atmospheric aerosols in Alta Floresta, Brazil: Multielemental composition and source apportionment, Nucl. Intsr. \& Methods B, 189, 243-248, 2002.

Maki, L. R. and Willoughby, K. J.: Bacteria as biogenic source of freezing nuclei, J. Appl. Meteorol., 17, 1049-1053, 1978.

Martin, C. L., Fitzjarrald, D., Garstang, M., Oliveira, A. P., Greco, S., and Browell, E.: Structure and growth of the mixing layer over the Amazonian rain forest. J. Geophys. Res., 93, 13611375, 1988.

Nemeruyk, G. E.: Migration of salts into the atmosphere during transpiration. Soviet Plant Physiol., 17, 560-566, 1970.

Novakov, T. and Penner, J. E.: Large contribution of organic aerosols to cloud-condensation- nuclei concentrations. Nature, 365, 823-826, 1993.

O'Dowd, C. D. and Smith, M. H.: Physicochemical properties of aerosols over the northeast Atlantic: Evidence for wind-speedrelated submicron sea-salt aerosol production, J. Geophys. Res., 98, 1137-1149, 1993.
Pöschl, U., Williams, J., Hoor, P., Fischer, H., Crutzen, P. J., Warneke, C., Holzinger, R., Hansel, A., Jordan, A., Lindinger, W., Scheeren, H. A., Peters, W., and Lelieveld, J.: High acetone concentrations throughout the $0-12 \mathrm{~km}$ altitude range over the tropical rainforest in Surinam, J. Atmos. Chem., 38, 115-132, 2001.

Prospero, J. M., Glaccum, R. A., and Nees, R. T.: Atmospheric transport of soil dust from Africa to South America , Nature, 289, 570-572, 1981.

Quinn, P. K., Bates, T. S., Miller, T. L., Coffman, D. J., Johnson, J. E., Harris, J. M., Ogren, J. A., Forbes, G., Anderson, T. L., Covert, D. S., and Rood, M. J.: Surface submicron aerosol chemical composition: What fraction is not sulfate? J. Geophys. Res.Atmos., 105, 6785-6805, 2000.

Roberts, G. C., Andreae, M. O., Zhou, J., and Artaxo, P.: Cloud condensation nuclei in the Amazon Basin: "Marine" conditions over a continent?, Geophys. Res. Lett., 28, 2807-2810, 2001.

Roberts, G. C., Artaxo, P., Zhou, J., Swietlicki, E., and Andreae, M. O.: Sensitivity of CCN spectra on chemical and physical properties of aerosol: A case study from the Amazon Basin, J. Geophys. Res., 107, article \# 8070, doi:10.1029/2001JD000583, 2002.

Rosenfeld, D.: Supression of rain and snow by urban and industrial air pollution, Science, 287, 1793-1796, 2000.

Scala, J. R., Garstang, M., Tao, W.-K., Pickering, K. E., Thompson, A. M., Simpson, J., Kirchhoff, V. W. J. H., Browell, E. D., Sachse, G. W., Torres, A. L., Gregory, G. L., Rasmussen, R. A., and Khalil, M. A. K.: Cloud draft structure and trace gas transport, J. Geophys. Res., 95, 17 015-17 030, 1990.

Schnell, R. C. and Vali, G.: Atmospheric ice nuclei from decomposing vegetation, Nature, 236, 163-165, 1973.

Sievering, H., Boatman, J., Galloway, J., Keen, W., Kin, Y., Luria, M., and Ray, J.: Heterogeneous sulfur conversion in sea-salt aerosol particles: The role of aerosol water content and size distribution, Atmos. Environ., 25A, 1479-1487, 1991.

Talbot, R. W., Andreae, M. O., Andreae, T. W., and Harriss, R. C.: Regional aerosol chemistry of the Amazon Basin during the dry season, J. Geophys. Res., 93, 1499-1508, 1988.

Werth, D. and Avissar, R.: The local and global effects of Amazon deforestation, J. Geophys. Res., 107, article \# 8087, doi:10.1029/2001JD000717, 2002.

Williams, J., de Reus, M., Krejci, R., Fischer, H., and Ström, J.: Application of the Variability-Size relationship to atmospheric aerosol studies: Estimating aerosol lifetimes, Atmos. Chem. Phys., 2, 133-145, 2002,

SRef-ID: 1680-7324/acp/2002-2-133.

Williams, J., Fischer, H., Hoor, P., Pöschl, U., Crutzen, P., Andreae, M. O., and Lelieveld, J.: The influence of the tropical rain forest on atmospheric $\mathrm{CO}$ and $\mathrm{CO}_{2}$ as measured by aircraft over Surinam, South America. Chemosphere, 3, 157-170, 2001.

Wouters, L., Hagedoren, S., Dierck, I., Artaxo, P., and Van Grieken, R.: Laser microprobe mass analysis of Amazon Basin aerosols, Atmos. Environ., 27A, 661-668, 1993.

Zhou, J., Swietlicki, E., Hansson, H. C., and Artaxo, P.: Submicrometer aerosol particle size distribution and hygroscopic growth measured in the Amazon rain forest during the wet season. J. Geophys. Res., 107, doi:10.1029/2000JD000203, 2001. 